\title{
Development and Evaluation of Small Tractor Drawn Seed Planter with Battery Operated Seed Metering Mechanism
}

\author{
N. Rakesh ${ }^{1 *}$, G. Veera Prasad ${ }^{1}$, Aum Sarma ${ }^{2}$ and H.V. Hema Kumar ${ }^{1}$ \\ ${ }^{1}$ College of Agricultural Engineering, ANGRAU, Bapatla - 522 101, India \\ ${ }^{2}$ Institute of Agricultural Engineering and Technology, PJTSAU, Hyderabad - 500 030, India \\ *Corresponding author
}

\begin{tabular}{|l|}
\hline K e y w o r d s \\
Dc motor, Field capacity, \\
$\begin{array}{l}\text { Fuel consumption, Seed } \\
\text { planter, Speed regulator, } \\
\text { Push button switch etc. }\end{array}$ \\
\hline Article Info \\
\hline $\begin{array}{l}\text { Accepted: } \\
\text { 16 February } 2018 \\
\text { Available Online: } \\
\text { 10 March } 2018\end{array}$ \\
\hline
\end{tabular}

\section{Introduction}

Rice is one of the most important food crops in India in term of both areas, production and consumer preference. The leading states in rice cultivation are Andhra Pradesh, West Bengal, and Uttar Pradesh. Andhra Pradesh ranked third with a cultivated area of 4.39 Mha and production of $13.80 \mathrm{Mt}$ with a yield of $3.15 \mathrm{t} / \mathrm{ha}$ in $2008-09$. In India, rice is an important ingredient of the household food
Small tractor operated seed planter with battery drive consists of a frame, furrow openers, individual seed boxes and battery drive, vertical rotor type seed metering mechanism, push button switch, and speed regulator. Seed metering mechanism gets a drive from the dc motor with aids of chain and sprocket arrangement instead of from ground wheel. As per the design calculations, the width of seed planter was $1.25 \mathrm{~m}$. Shoe type furrow openers were selected to open the furrow. No. of furrow openers and row to row spacing was 5 no.s and $25 \mathrm{~cm}$ respectively. Length of simplex chain, the pitch of the chain and no. of links was $43 \mathrm{~cm}, 1.5 \mathrm{~cm}$, and 29 respectively. No. of teeth on sprocket and gear ratio was 12 and $1: 1$ respectively. Capacity of the seed box was $1 \mathrm{~kg}$ per one furrow, length, and diameter of the feeder shaft was $104 \mathrm{~cm}$ and $1.5 \mathrm{~cm}$ respectively, $12 \mathrm{vDc}$ motor was selected for operating the seed metering mechanism instead of a ground wheel. Speed of the dc motor was $100 \mathrm{rpm}$ and regulator was selected for setting Dc motor speed according to tractor rear wheel speed in different gears. To avoid wastage of seed in turnings the push button switch was selected to disconnect the motor from the power supply. Small tractor operated seed planter with battery drive metering mechanism evaluated for its performance, results shown that the field capacity, field efficiency of the planter, fuel consumption, seed to seed spacing, depth of sowing and germination of seed was $0.30 \mathrm{ha} / \mathrm{h}, 66.17 \%, 1.87 \mathrm{lit} / \mathrm{h}$, $23.2 \mathrm{~cm}, 5.4 \mathrm{~cm}$ and $97 \%$ respectively. 
adopted dry seeding of rice directly in the field with the onset of monsoons and converting the dry field into wet condition as soon as canal water is released. For dry seeding of paddy, the avialable machinery are multi-crop seed drill fitted with fluted roller metering mechanism driven by the ground wheel and having tyne furrow openers. In seed drills the problems identified are unequal seed placement in a row, excessive seed dropping, clogging of seed tubes due to soil intrusion and strucking of the ground wheel in sticky soils (Srigiri et al., 2012).

To overcome these problems there is a need for precise seed drill for the direct dry sowing of paddy without any problem even in adverse conditions. Considering the above problems with existing machinery and popularity of small tractors, the small tractor operated planter was developed with battery operated metering mechanism and evaluated for its performance.

\section{Materials and Methods}

Components of the planter include the frame, seed hopper, seed metering mechanism, power transmission system, seed delivery tube, furrow opener etc. Details of the components were described below.

\section{Frame}

Frame was made with square hallow bars having dimensions of $5 \times 5 \mathrm{~cm}$ as per designed calculations for connecting to the tractor three points hitching system and provide support to the seed hopper and furrow openers. Dimensions of the frame were shown in figure 1 .

\section{Seed hopper}

Seed container as the name implies was a device in which the seeds to be planted are kept before their gradual release into the furrowed tunnel. Hopper has the shape of a frustum of a pyramid truncated at the top and also has a gate with a handle on top to easy opening. Seed hopper is shown in figure 2 . Design of hopper depends on physical properties of seeds so the physical properties of seeds measured by standard procedures (Jouki and Khazaei, 2012; Jayan and Kumar, 2004). Physical properties of seed are shown in table 1.

\section{Shaft}

Shaft having a diameter of $15 \mathrm{~mm}$ and 1040 mm length was selected based on design calculations for mounting sprockets and seed metering plates. Shaft diameter was calculated by considering shaft subjected to twisting moment (Rajkiran et al., 2015) Shaft dimensions are shown in figure 3.

\section{Seed metering plates}

Seed metering device used in this planter is the vertical rotor type with cells on its periphery. Size and number of cells on the rotor depends on the size of the seed and desired seed rate.

In this design, the vertical rotor lifts the seeds with cells and drops these into the seed funnel which is conveyed to the open furrow through the seed tube. Diameter and no. of cells on seed plate was calculated by considering the gear ratio and plant to plant spacing respectively (Sharma and Mukesh, 2013).

\section{Chain sprocket}

Sprockets are selected according to the speed ratio and power requirement. Sprocket diameter on the motor shaft is equal to the sprocket on the metering shaft.

The pitch of the sprockets is $15 \mathrm{~mm}$, number of teeth on the sprocket are 12 . 


\section{DC motor}

$100 \mathrm{rpm}$ side shaft super heavy duty dc gear motor was selected for operating the seed metering mechanism. Motor has a sturdy construction with large gears. Drive shaft is supported from both sides with metal bushes.

Motor runs smoothly from $4 \mathrm{~V}$ to $12 \mathrm{~V}$ and gives $100 \mathrm{rpm}$ at $12 \mathrm{~V}$. Motor has $8 \mathrm{~mm}$ diameter, $19 \mathrm{~mm}$ length drive shaft with DShape for excellent coupling. But, this motor will be bit noisy while running.

Dc motor selected on the basis of the battery power, torque to turn the shaft and to meet the rpm of the rear wheel of the tractor.

\section{DC motor speed regulator}

DC motor speed regulator compatible for $12 \mathrm{~V} / 24 \mathrm{~V} / 36 \mathrm{~V}$ batteries was selected for regulating the speed of the motor. Selection of existing PCB was done by considering the electric power source (Battery) voltage and current.

Dc motor speed regulator terminals were correctly connected to the dc power supply. Mismatching of terminals gets a short circuit.

\section{Push button switch}

Push button switch was used open the circuit to stop the flow of electricity to the motor. In working conditions, the seed planter has to lifts at turnings of the field to avoid the wastage of seeds.

In this design, dc motor was used to maintain the required speed instead of a ground wheel. When the hydraulic lever was reached to top position the lever pushes the switch to stop the power transmission. When hydraulic lever moves down the power was supplied to the motor.

\section{Seed tube and furrow opener}

Seed tube and furrow opener were designed by considering the required depth of seed placement (Collins and Fowler, 1996). Seed tube of $25 \mathrm{~mm}$ diameter transparent plastic pipe having $2 \mathrm{~mm}$ wall thickness was selected and attached to the bottom of seed hopper. Height of the seed delivery spout was close to the ground to achieve seed spacing uniformity. Height of the shank was $200 \mathrm{~mm}$. Shoe type furrow bottom was bolted to the shank and that is attached to the main frame with rigid clamps. Seeds were adequately covered by the flow of loose soil during operation. Hence, there was no need of separate covering device.

\section{Power transmission system}

In this system, the flow of electricity starts from dc power outlet (small tractor rear side) to $\mathrm{dc}$ motor speed regulator circuit board. From regulator circuit board the electricity transfers to dc motor. In between regulator circuit board and dc motor the push button switch is connected to stop the electricity when the planter is at lifted position. From dc motor the power transfers to the seed metering shaft which rotates the seed plates to pick up the seed.

\section{Results and Discussion}

\section{Performance evaluation of seed planter}

Small tractor operated seed planter was evaluated for its performance at College of Agricultural Engineering, Bapatla. Results are shown in the following table 2.

From tests the results shown that the field capacity, field efficiency of the planter, fuel consumption, seed to seed spacing, depth of sowing and germination of seed was 0.30 $\mathrm{ha} / \mathrm{h}, 66.17 \%, 1.87 \mathrm{lit} / \mathrm{h}, 23.2 \mathrm{~cm}, 5.4 \mathrm{~cm}$ and $97 \%$ respectively. 
Fig.1 Frame

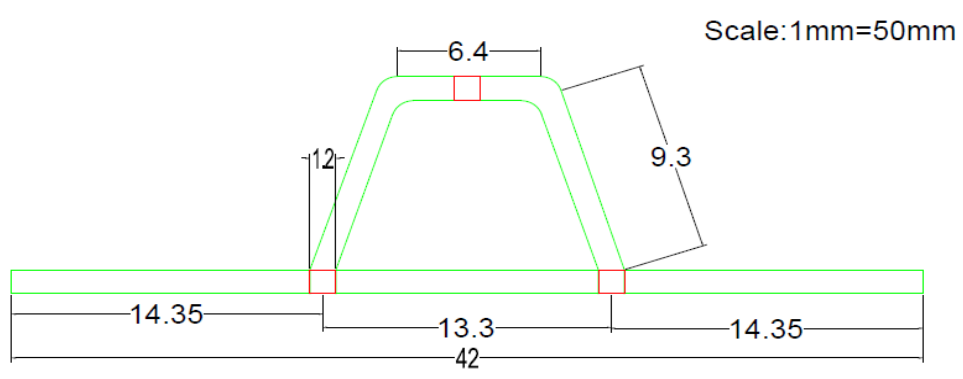

All dimensions are in $\mathrm{mm}$

Fig.2 Seed hopper

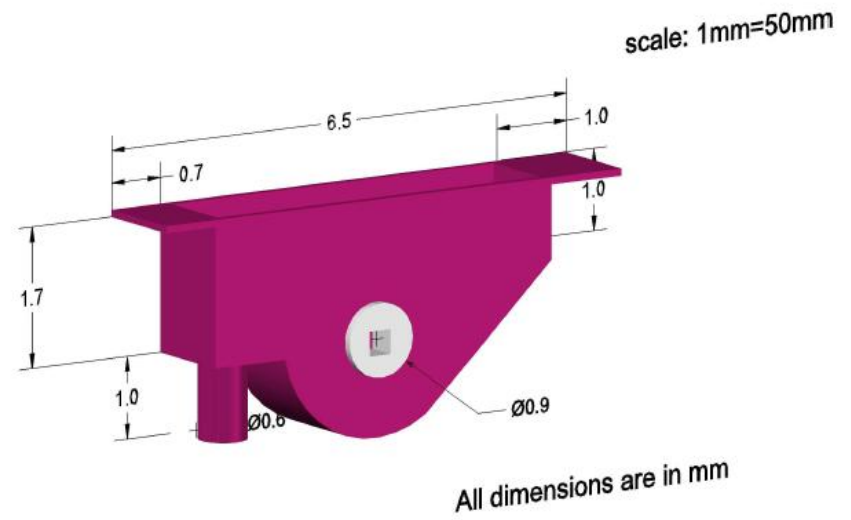

Fig.3 Shaft

15 1040 Al dimensions are in $\mathrm{mm}$

Fig.4 Seed metering plate

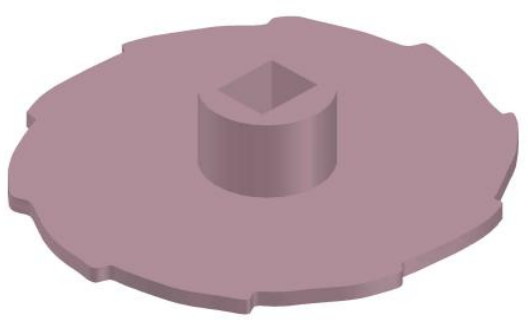

Fig.5 Side shaft super heavy duty dc gear motor 


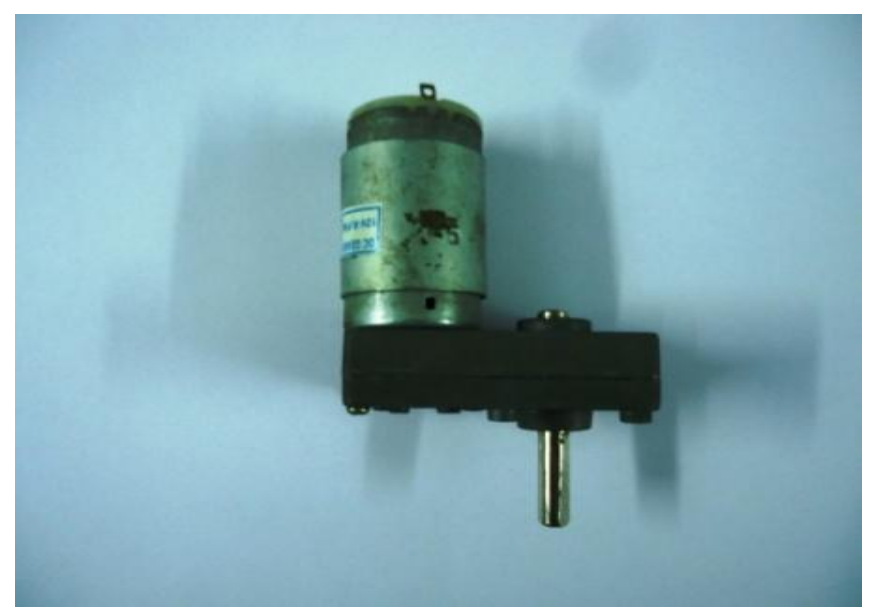

Fig.6 Mounting of dc motor on seed planter

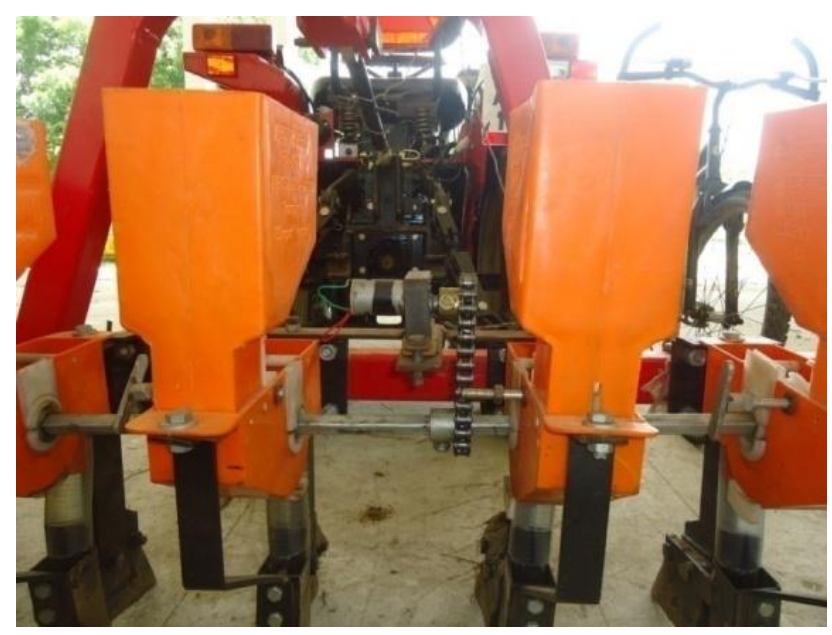

Fig.7 DC Motor speed regulator

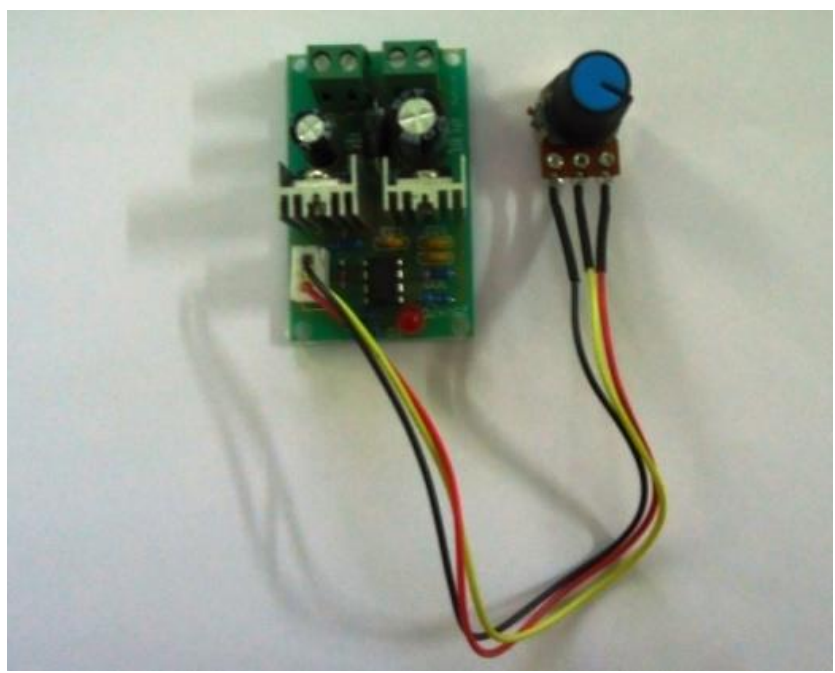

Fig.8 Fixing of DC motor speed regulator 


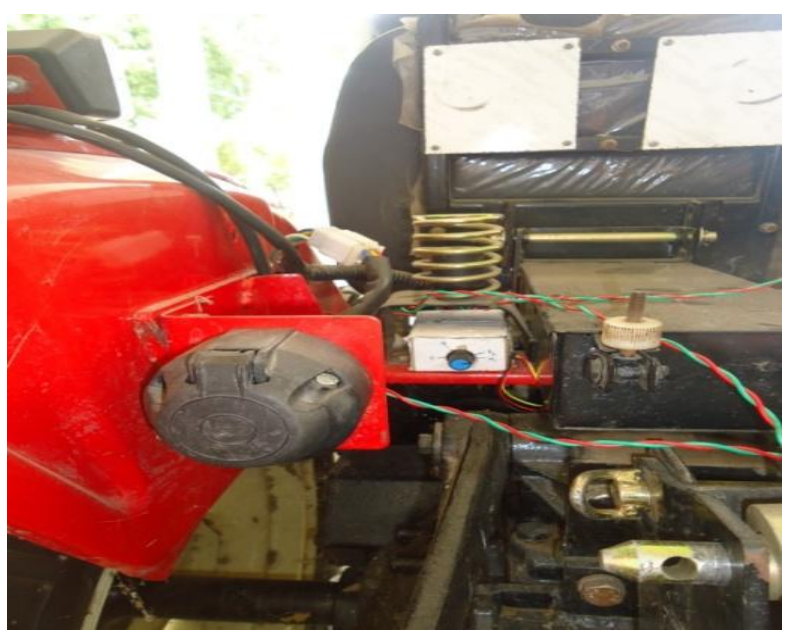

Fig.9 Push button switch

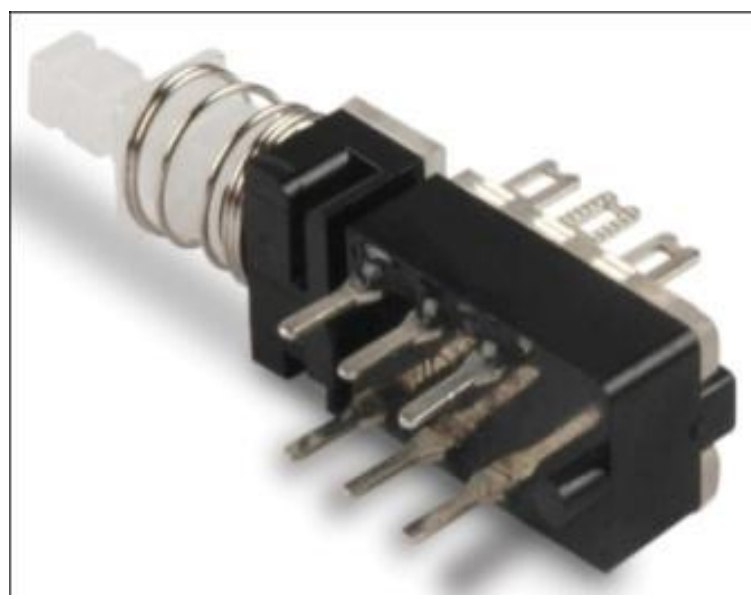

Fig.10 Fixing of push button switch

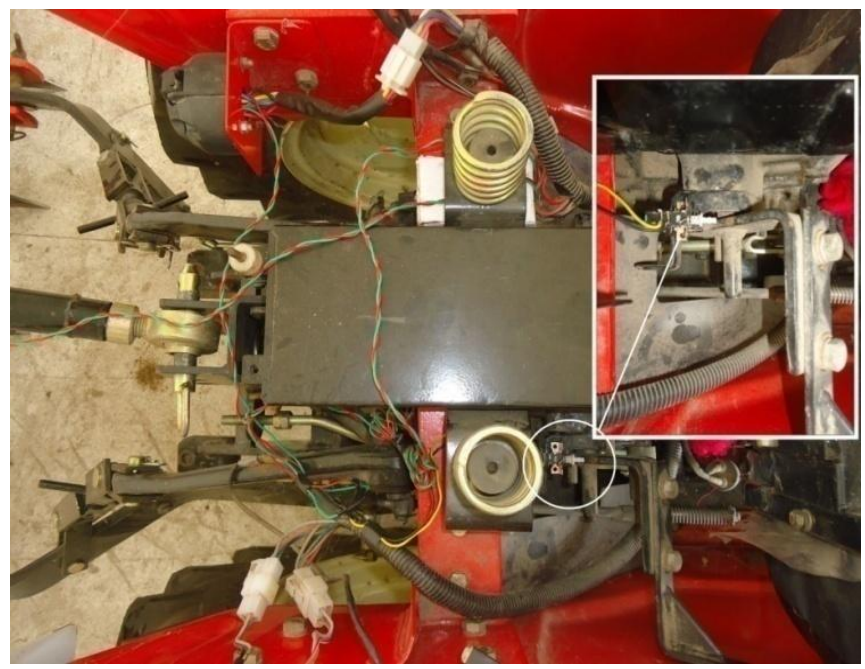


Fig.11 Furrow opener

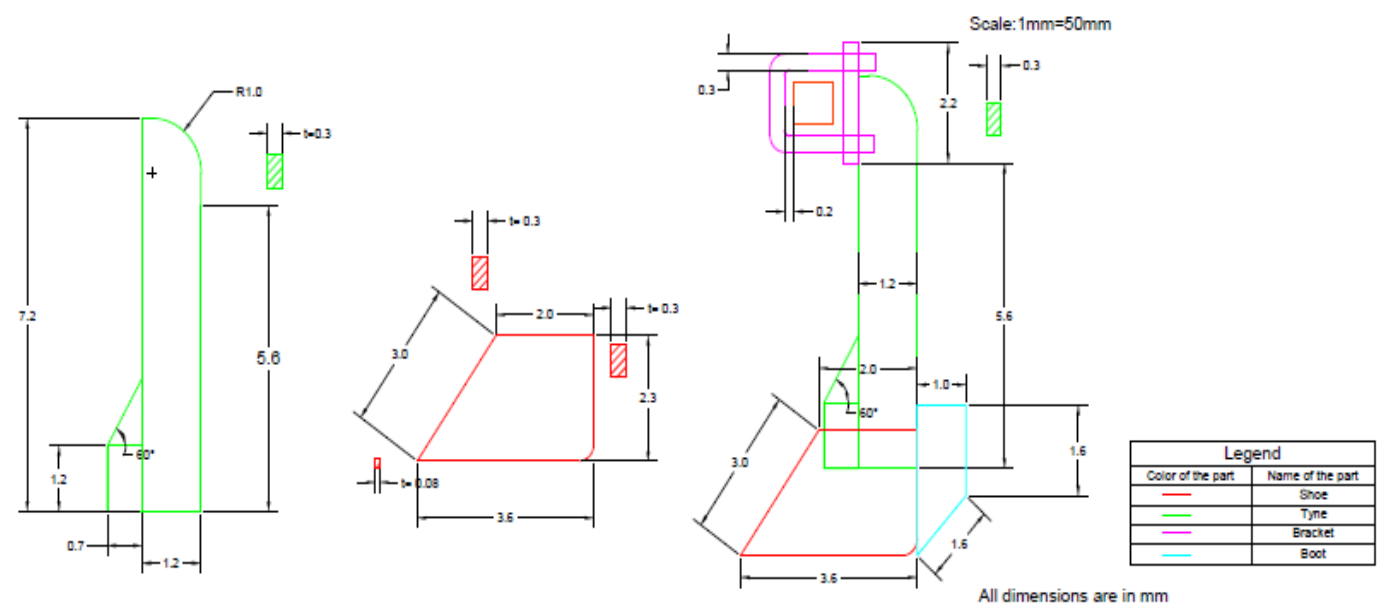

Fig.12 Power transmission system

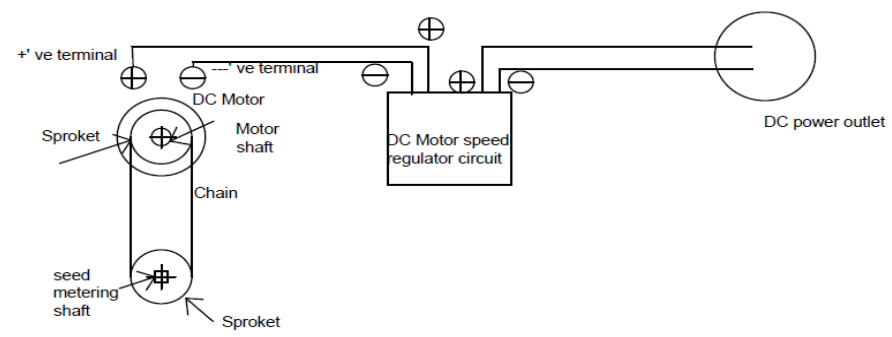

Table.1 Physical properties of seed $($ BPT5204) $($ Moisture content $=13 \% \mathrm{db})$

\begin{tabular}{|c|c|c|c|c|c|c|}
\hline Trails & $\begin{array}{c}\text { Length, } \\
\text { mm }\end{array}$ & $\begin{array}{c}\text { Width, } \\
\text { mm }\end{array}$ & $\begin{array}{c}\text { Thickness, } \\
\text { mm }\end{array}$ & $\begin{array}{c}\text { 1000 seeds } \\
\text { weight, }\end{array}$ & $\begin{array}{c}\text { Bulk density, } \\
\text { kg/m } \mathbf{3}\end{array}$ & $\begin{array}{c}\text { Angle of } \\
\text { repose, deg }\end{array}$ \\
\hline $\mathbf{1}$ & 7.44 & 2.11 & 1.78 & 13.5 & 581 & 33.42 \\
\hline $\mathbf{2}$ & 8.27 & 2.07 & 1.79 & 14.2 & 585 & 34.21 \\
\hline $\mathbf{3}$ & 8.04 & 2.12 & 1.80 & 15.2 & 590 & 32.62 \\
\hline Average & 7.92 & 2.10 & 1.79 & 14.3 & 585.3 & 33.42 \\
\hline
\end{tabular}

Table.2 Performance evaluation of a seed planter

\begin{tabular}{|c|c|c|c|c|c|c|}
\hline Trails & $\begin{array}{c}\text { Field } \\
\text { capacity, ha/h }\end{array}$ & $\begin{array}{c}\text { Fuel } \\
\text { consumption, } \mathbf{l} / \mathbf{h}\end{array}$ & $\begin{array}{c}\text { Seed to seed } \\
\text { spacing, cm }\end{array}$ & $\begin{array}{c}\text { Depth of } \\
\text { sowing, cm }\end{array}$ & $\begin{array}{c}\text { Germination, } \\
\text { \% }\end{array}$ & $\begin{array}{l}\text { Field } \\
\text { efficiency, \% }\end{array}$ \\
\hline $\mathbf{1}$ & 0.29 & 1.89 & 26.1 & 5.5 & 98 & 64.22 \\
\hline $\mathbf{2}$ & 0.30 & 1.83 & 25.1 & 5.2 & 97 & 66.25 \\
\hline $\mathbf{3}$ & 0.31 & 1.89 & 18.3 & 5.5 & 96 & 68.04 \\
\hline Average & 0.30 & 1.87 & 23.2 & 5.4 & 97 & 66.17 \\
\hline
\end{tabular}


As per the design, the width of seed planter was $1.25 \mathrm{~m}$. Shoe type furrow opener was selected and no. of furrow openers, row to row spacing was $5,25 \mathrm{~cm}$ respectively. Length of the simplex chain, pitch of the chain and no. of links was $43 \mathrm{~cm}, 1.5 \mathrm{~cm}$ and 29 respectively. No. of teeth on sprocket and gear ratio was 12 and 1:1 respectively. Capacity of the seed box was $1 \mathrm{~kg}$ per one furrow. Length and diameter of the feeder shaft were $104 \mathrm{~cm}$ and $1.5 \mathrm{~cm}$ respectively. $12 \mathrm{vdc}$ motor was selected for operating the seed metering mechanism instead of a ground wheel. DC motor speed was 100rpm and the regulator was selected for setting dc motor speed according to tractor rear wheel speed in different gears. To avoid wastage of seed in turnings the push button switch was selected to disconnect the motor from the power supply. Small tractor operated seed planter with battery drive metering mechanism evaluated for its performance and results shown that the field capacity, field efficiency of the planter, fuel consumption, seed to seed spacing, depth of sowing and germination of seed was $0.30 \mathrm{ha} / \mathrm{h}, 66.17 \%, 1.87 \mathrm{lit} / \mathrm{h}$, $23.2 \mathrm{~cm}, 5.4 \mathrm{~cm}$ and $97 \%$ respectively.

\section{References}

Atul Kumar Shrivastava and Satyendra Jha. 2011. Modification and Performance Evaluation of Tractor Drawn Improved Till Plant Machine under Vertisol. Agricultural Engineering International: the CIGR Journal. 13(2):1-11.

Barah, B.C. 2009. Economic and Ecological Benefits of system of Rice Intensification (SRI) in Tamil Nadu.

\section{How to cite this article:}

Rakesh, N., G. Veera Prasad, Aum Sarma and Hema Kumar, H.V. 2018. Development and Evaluation of Small Tractor Drawn Seed Planter with Battery Operated Seed Metering Mechanism. Int.J.Curr.Microbiol.App.Sci. 7(03): 1879-1886.

doi: https://doi.org/10.20546/ijcmas.2018.703.223
Agricultural Economics Research Review. 22: 209-214.

Collins, B.A and Fowler, D. B. 1996 Effect of soil characteristics, seeding depth, operating speed, and opener design on draft force during direct seeding. Soil and Tillage Research. 39: 199-211.

Dineshkumar Rangapara and Pandya Jaimin. 2014. Performance Evaluation of Manually Operated Single Row Cotton Planter. International Journal of Engineering Sciences and Research Technology. 3(9): 40-44.

Jayan, P.R and Kumar, V.J.F. 2004. Planter design in relation to the physical properties of seeds. Journal of Tropical Agriculture. 42 (1-2): 69-71

Jouki, M and Khazaei, N.2012. Some Physical Properties of Rice Seed (Oryza sativa). Research Journal of Applied Sciences, Engineering and Technology. 4(13): 1846-1849.

Rajkiran, B., Rakesh, N., Naga Jyothi, M., and Ramarao A. 2015. Design and Evaluation of Push Type Rotary Tiller. The Andhra Agricultural Journal.62 (1):190-197.

Sharma, D.N and Mukesh. S. 2013. Design of tractor Drawn multipurpose sowing machine for ridge-furrow and flatbed system. Farm machinery design principles and problems. Ed. 3:163-181.

Srigiri, D., Hemanth Reddy, A., Sri Rama Satish, P., Amruth Sai and Hari babu, B. 2013. Case study on direct sowing of paddy in selected mandals of Guntur district. B. Tech Thesis. College of Agricultural Engineering, Bapatla. 